\title{
In vitro evaluation of the antibacterial behavior of a self-etch adhesive associated with chlorhexidine
}

\author{
Avaliação in vitro da ação anti-bacteriana de um adesivo auto-condicionante \\ acrescido de clorexidina
}

\author{
Roberta Bento RODRIGUES ${ }^{a}$ (D) Nereida Mello GIOPPO ${ }^{a}$ (D), Priscilla do Monte Ribeiro BUSATO ${ }^{\text {(D) }}$, \\ Marcio José MENDONÇA ${ }^{a}$ (D), Veridiana CAMILOTTIa* (D) \\ aUNIOESTE - Universidade Estadual do Oeste do Paraná, Faculdade de Odontologia, Cascavel, PR, Brasil \\ ${ }^{b}$ Associação Brasileira de Odontologia, Especialização em Dentística Restauradora, Cascavel, PR, Brasil
}

How to cite: Rodrigues RB, Gioppo NM, Busato PMR, Mendonça MJ, Camilotti V. In vitro evaluation of the antibacterial behavior of a self-etch adhesive associated with chlorhexidine. Rev Odontol UNESP. 2019;48:e20170094.

https://doi.org/10.1590/1807-2577.09417

\section{Resumo}

Introdução: A tecnologia adesiva vem se desenvolvendo rapidamente desde que foi introduzida há mais de 50 anos. 0 principal objetivo da adesão é alcançar um íntimo contato entre a estrutura dental e o material restaurador e fornecer adequada união entre o esmalte e a dentina. Objetivo: A proposta deste estudo foi avaliar o efeito antibacteriano de um adesivo auto-condicionante de dois passos associado a diferentes concentrações de solução de digluconato de clorexidina (DCHX). Metodologia: A solução de digluconato de clorexidina a 20\% foi adicionada ao primer do sistema adesivo nas concentrações de 0,5, 1,0 e 2,0\% e distribuídas em quatro grupos (G1, G2, G3 e G4). Para o teste de atividade antibacteriana foram utilizadas amostras de saliva $(\mathrm{N}=10)$ semeadas em meio de ágar sangue e discos de papel filtro contendo os diferentes grupos. Após incubação, as amostras foram inspecionadas quanto à formação de halo de inibição dos microrganismos através da utilização do paquímetro digital de precisão $(0,0001 \mathrm{~mm})$ (Mitutoyou Sul Americana Ltda/ Starret Tools ${ }^{\circledR}$ ). Resultado: Halos de inibição foram encontrados ao redor de todos os discos de filtro em que foram aplicados o primer acrescido de clorexidina mais o adesivo, bem como ao redor dos discos do controle positivo. Ao redor dos discos do controle negativo e dos discos com primer e adesivo não modificado não foram observados halos de inibição. Conclusão: Este trabalho demonstrou que, in vitro, a adição de diferentes concentrações de digluconato de clorexidina ao sistema adesivo produziu halo de inibição dos microrganismos presentes nas amostras de saliva, independente da concentração utilizada.

Descritores: Adesivo dentinário; dentina; agente antibacteriano.

\begin{abstract}
Introduction: Adhesive technology has been developed quickly since its introduction about fifty years ago. Its goal is to produce a close contact within enamel and dentin. Failures in this process could result in microleakage, and allow the infiltration of bacteria, fluids and ions. Recent studies have been shown the use of chlorhexidine associated with adhesive systems can be able to inhibit the bacteria action. Objective: The aim of this study was to evaluate the addiction of different percentages of chlorhexidine to a self-etch adhesive. Methodology: The solution of digluconatechlorhexidine was increased to the primer of the two pass self etch adhesive to create a $0.5 \%, 1.0 \%$ and $2.0 \%$ chlorhexidine primer solution and after they were distributed in four groups (G1, G2, G3 and G4). Saliva samples ( $\mathrm{N}=10)$ were used to test bacteria activity. Result: They were spread in a blood medium with filter paper disks containing the different treatments. After the incubation, the inhibitions halos formation were evaluated. Conclusion: This study demonstrated that, in vitro, the addition of different percentages of chlorhexidine digluconate to the self-etch adhesive induced inhibited halos at bacteria of saliva samples, independent from their concentration.
\end{abstract}

Descriptors: Dentin adhesive; dentin; anti-bacterial agents. 


\section{INTRODUCTION}

Adhesive technology has developed rapidly since its introduction, over 50 years ago ${ }^{1-4}$. The main purpose of adhesion is to allow for a close contact between dental structure and the restoring material as well as to provide proper union between enamel and dentin. Since the dentin structure is less mineralized and contains a greater amount of collagen fibers and water, adhesion to it is hindered compared to enamel, a highly mineralized structure ${ }^{1,3,5}$.

Maintaining bonding integrity and marginal sealing is key to keeping pulp vitality and increasing the clinical longevity of restorations. These are some of the challenges to be overcome in restorations with no enamel at the cervical margin. As they are in close contact with the marginal periodontium and gingival crevicular fluid, these cavities require proper marginal sealing without defects or excess restoration material in order to prevent plaque accumulation and gingival inflammation. Marginal defects in cervical restorations may be attributed to stress caused by occlusal forces concentrated in the cervical region, which result in detachment, staining, and insufficient retention, besides infiltration into the adhesive interface ${ }^{5}$.

Adhesive interface degradation and forming of GAPS may result in the penetration of bacteria, fluids, or ions between the cavity wall and the composite resin. This process is called marginal microleakage ${ }^{3}$. However, degradation may affect other components besides the hybrid layer, such as the collagen matrix. When collagen fibers are exposed to resinous monomers, they are vulnerable to the action of collagenolytic enzymes activated by dental plaque bacteria segregation or by the activation of matrix metalloproteinases (MMPs) and cysteine cathepsins, which degrade the interface between the restorative material and the dental substrate ${ }^{5-9}$. Different adhesive systems have been introduced with a view to reduce marginal microleakage of composite resin restorations. Nevertheless, the vast majority is still not entirely efficient in preventing it ${ }^{10}$. Recent studies have shown that the use of chlorhexidine (CHX) associated with the adhesive system may inhibit the action of MMPs and cysteine cathepsins $6,8,11$.

In 2003, Imazato ${ }^{7}$ discussed the advantages of adding antimicrobial agents to resin materials, such as dental composites and adhesive systems, with the purpose of preventing biofilm formation around restorations, where the use of CHX may be an option. The compound was discovered in 1940 and was first used in 1954 as a topical antiseptic. Its most common presentation is digluconate, whereas it can also be found as acetate and hydrochloride. Acting against yeast and bacterial infections, this chemical antiseptic eliminates both gram-positive and gram-negative bacteria. In addition, it is a bacteriostatic agent, capable of inhibiting reproduction of bacteria ${ }^{12-14}$. The possibility of adding low CHX concentrations to resin materials without causing major changes to their physicochemical properties has been pointed out in previous studies ${ }^{14,15}$. Antimicrobial action assessment is an important step in the development of novel restoration materials ${ }^{12}$.

Therefore, this study aimed to assess the antimicrobial effect of a two-step self-etching adhesive in association with different concentrations of chlorhexidine digluconate (DCHX).

\section{METHODOLOGY}

\section{Sampling}

The oral microbiota saliva samples $(n=10)$ used in this research are a part of the samples presenting cultures discarded by the Bacteriology Department of Laboratório de Análises Clínicas [Clinical Pathology Laboratory] of Hospital Universitário do Oeste do Paraná, in Cascavel, state of Paraná (Brazil). 


\section{Preparation of the Self-etching Adhesive with Chlorhexidine}

The two-step self-etching adhesive AdheSe ${ }^{\circledR}$ (IvoclarVivadent, Sacha, Lichestein, Germany) was used in this study. The chlorhexidine digluconate $20 \%$ in aqueous solution was added to the self-etch adhesive primer in three different chlorhexidine concentrations: $0.5 \%, 1 \%$, and $2 \%$, based on the work of Araújo et al. ${ }^{5}$ (Table 1 and 2), distributed into 4 experimental groups (G1, G2, G3, and G4) and 2 control groups (CP,CN), according to Table 3.

Table 1. Description of materials

\begin{tabular}{ll}
\hline \multicolumn{1}{c}{ MATERIAL } & \multicolumn{1}{c}{ COMPOSITION } \\
\hline & Primer: dimethacrylate, phosphonic acid acrylate, initiators and stabilizers, \\
AdheSe Adhesive & water \\
(Ivoclair/Vivadent) & $\begin{array}{l}\text { Adhesive: 2-Hydroxyethyl methacrylate (HEMA), dimethacrylate, silicon } \\
\text { dioxide, initiators and stabilizers }\end{array}$ \\
Chlorhexidine Digluconate 20\% & Chlorhexidine digluconate 20\% in aqueous solution \\
\hline
\end{tabular}

Table 2. Composition of chlorhexidine digluconate and AdheSe ${ }^{\circledR}$ adhesive in different concentrations

\begin{tabular}{lccc}
\hline \multicolumn{1}{c}{ MATERIAL } & \multicolumn{3}{c}{ Quantity } \\
\cline { 2 - 4 } & $\mathbf{0 . 5 \%}$ & $\mathbf{1 \%}$ & $\mathbf{2 \%}$ \\
\hline AdheSe (Ivoclair/Vivadent) Adhesive & $487.5 \mu \mathrm{l}$ & $475 \mu \mathrm{l}$ & $450 \mu \mathrm{l}$ \\
Chlorhexidine Digluconate 20\% & $12.5 \mu \mathrm{l}$ & $25 \mu \mathrm{l}$ & $50 \mu \mathrm{l}$ \\
\hline
\end{tabular}

Table 3. Distribution of material in different concentrations among the the sample (G1, G2, G3, and G4) and control groups

\begin{tabular}{ccc}
\hline Group & Group composition \\
\hline G1 & ADH $500 \mu \mathrm{l}$ \\
G2 & ADH + CHX $-0.5 \%$ \\
G3 & ADH + CHX $-1 \%$ \\
G4 & ADH + CHX $-2 \%$ \\
CP & CHX $20 \%$ \\
CN & Sterile filter paper discs \\
\hline
\end{tabular}

$\mathrm{ADH}=\mathrm{AdheSe}^{\circledR}$ Adhesive; $\mathrm{CHX}=$ Chlorhexidine Digluconate; $\mathrm{CP}=$ positive control; $\mathrm{CN}$ = negative control.

\section{Agar Diffusion Test (ADT)}

Saliva samples from oral microbiota were cultivated in blood agar plates incubated at $37 \pm 2^{\circ} \mathrm{C}$ for 24 hours. After the colonies' growth, inocula were prepared for the agar diffusion test (ADT). A sterile swab was used to randomly collect the different colonies present in the blood agar and inoculated in saline up to turbidity 05 on McFarland's scale, equivalent to $1.5 \times 10^{8} \mathrm{CFU} / \mathrm{mL}$ of saline. For the McFarland scale preparation, we used a barium sulfate suspension, which is compared to the inoculum prepared for each microorganism alongside the tube with McFarlane scale's standard turbidity for visual comparison. Tube 0.5 of McFarland scale, equivalent to $1.5 \times 108 \mathrm{CFU} / \mathrm{mL}$ of the medium (Colony Forming Units), was used in this study Since the inoculum is made of pure and recent cultures and previously identified microorganisms, it is known that the microorganism growth curve is in the log phase, where microorganisms multiply exponentially.

The ADT was carried out in Petri dishes half filled with blood agar. Four paper discs of $4 \mathrm{~mm}$ in diameter, made with a paper punch and properly sterilized, were positioned on the dishes according to the groups described in Table 2 and the positive and negative control groups. The 
agar plates containing the samples were incubated for $24 \mathrm{~h}$ in a bacteriological incubator at $37 \pm 2{ }^{\circ} \mathrm{C}$. Then, they were inspected as to the formation of microorganism inhibition zones. The longest zone diameter was measured with the aid of a precision digital caliper $(0.0001 \mathrm{~mm})$ (Mitutoyou Sul Americana Ltda/ Starret Tools ${ }^{\circledR}$ ). All samples were performed in duplicate. Swabs were also collected from each sample of oral microbiota and stained by the Gram method. A subsequent analysis of the morphological and staining characteristics was carried out (Figure 1).

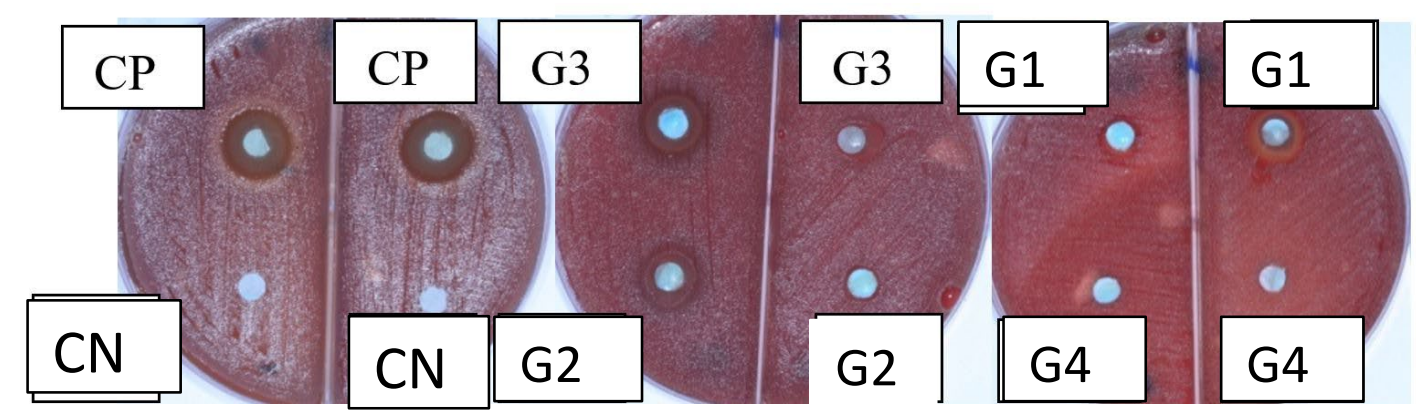

Figure 1. Images representing the culture media: experimental and control groups. $\mathrm{CP}=$ positive control (with chlorhexidine); $\mathrm{CN}=$ control (paper disc only); G1 = ADH $500 \mu \mathrm{l} ; \mathrm{G} 2=\mathrm{ADH}+\mathrm{CHX}-0.5 \%$; $\mathrm{G} 3=\mathrm{ADH}+\mathrm{CHX}-1 \% ; \mathrm{G} 4=\mathrm{ADH}+\mathrm{CHX}-2 \%$.

\section{Morphological and Staining Characteristics}

After collecting swabs from each sample of oral microbiota, they were stained by Gram's method and a subsequent analysis of the morphology and staining characteristics was carried out (Table 4).

Table 4. Morphology and staining characteristics of samples stained by Gram's method

\begin{tabular}{cccccc}
\hline \multirow{2}{*}{ SAMPLES } & \multicolumn{5}{c}{ MORPHOLOGY AND STAINING CHARACTERISTICS } \\
\cline { 2 - 6 } & GPC & GNC & GPB & GNB & LEV \\
\hline 01 & +++ & + & + & ++ & NF \\
02 & Rare & +++ & NF & rare & NF \\
03 & + & +++ & NF & rare & NF \\
04 & + & +++ & ++ & rare & + \\
05 & ++ & +++ & + & NF & NF \\
06 & ++ & +++ & + & NF & NF \\
07 & +++ & ++ & ++ & + & NF \\
08 & +++ & ++ & ++ & rare & NF \\
09 & +++ & rare & ++ & NF & NF \\
10 & ++ & +++ & rare & rare & NF \\
\hline
\end{tabular}

GPC = Gram-positive cocci; GNC = Gram-negative cocci; GPB = Gram-positive bacilli; GNB = Gram-negative bacilli; LEV = yeasts; $\mathrm{NF}=$ Not foud.

\section{Statistical Analysis}

The mean values $(\mathrm{mm})$ of inhibition zones obtained were analyzed with software Bioestat 5.3 (Instituto de DesenvolvimentoSustentávelMamirauá, Tefé-AM). For such, the values were initially submitted to the Shapiro-Wilk normality test. Considering the positive result of 
adherence to normality curve, the data was submitted to a one-way Analysis of Variance, ANOVA, and afterwards, to Tukey's test, $\mathrm{p}<0.05$.

\section{RESULT}

Analysis of the results has shown a statistically similar presence of inhibition zones around all filter discs in which the chlorhexidine-containing primer and the adhesive had been applied $(p<0.05)$. As to the comparison between inhibition zones formed by the groups to which the chlorhexidine-containing primer was applied, statistically significant differences were found (Figure 2).

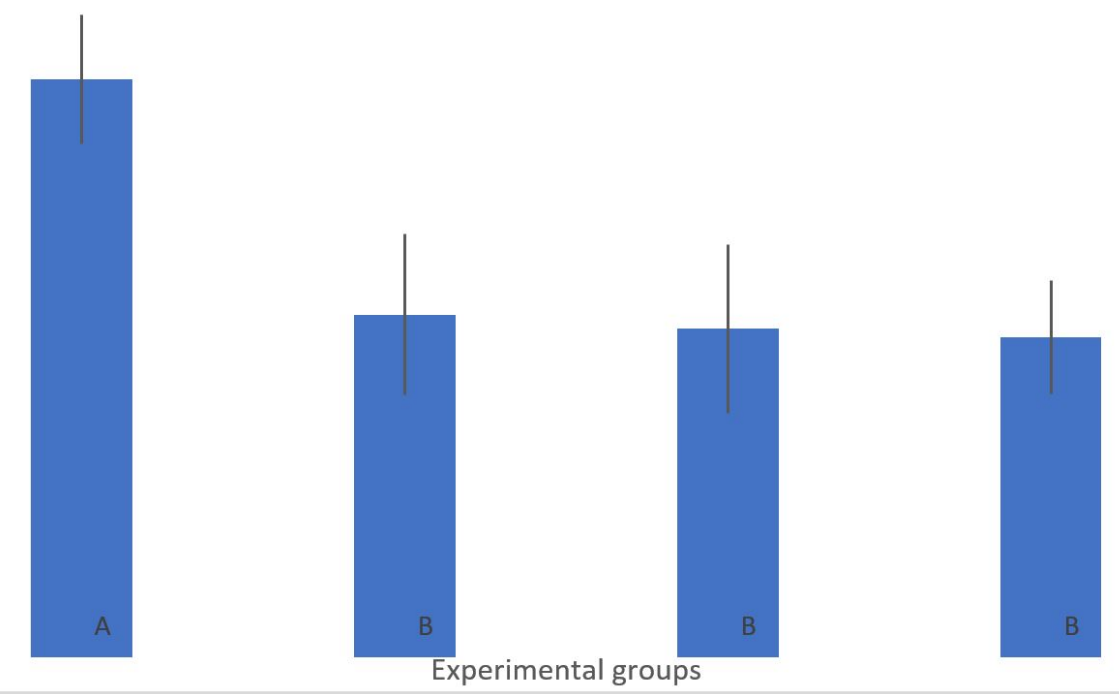

Figure 2. Mean $(\mathrm{mm}) \pm$ standard deviation of quantitative variable in relation to experimental groups. Different letters indicate statistical differences between the groups $(p<0.05)$.

\section{DISCUSSION}

In this study, inhibition zones were observed in all groups, with the exception of the negative control. This shows that the adhesive system used does not have antibacterial effect without CHX. Similar results have been found by Licio et al. ${ }^{13}$, where adhesive systems Adper Single Bond 2 and Ambar Universal did not have an antibacterial effect in the absence of CHX. This might justify research including antimicrobial agents in adhesive systems. The efficacy of CHX as an antimicrobial or antiproteolytic agent has been reported to be related with its substantivity to the oral/dental structures ${ }^{14}$. Substantivity is the prolonged retention of a given material (e.g. CHX) in a substrate (e.g. oral mucosa, bacterial plaque, and tooth surface). This association may be greater and more comprehensive than a simple deposition mechanism. It is considered that the biologically active agent penetrates the dentinal tubules in effective dosages, which increases its effects for long periods of time ${ }^{15}$.

Several authors ${ }^{16-18}$ suggest that the adhesive systems' bactericidal activity is affected by attributes inherent of each material, such as $\mathrm{pH}$, viscosity, diffusing capacity and, of course, the presence of antibacterial agents. In view of the acid pH of self-etch adhesives, it is suggested that a higher acidity of primers would account for the bactericidal activity of these materials. However, other recent studies have not found a significant relation between the acidity of self-etch 
adhesives and its antibacterial effects ${ }^{16,19-22}$. The present study did not find this characteristic either, since none of the microbiota samples formed inhibition zones.

Adhesive materials may be modified by two methods: the addition of soluble antibacterial agents and the immobilization of antibacterial components of the matrix or adhesive systems ${ }^{21}$. Some works have reported harmful events following the addition of soluble antibacterial agents to adhesive materials, among them a drastic and rapid decrease of the antibacterial agent's levels, difficulty to understand this process' kinetics, and the adverse effects in the physical and mechanical properties of the materials ${ }^{22}$.However, in vitro studies have shown that adding low concentrations of $\mathrm{CHX}$ does not change the physical and mechanical properties of the materials, which corroborates the findings of this study.

The agar plate is the simplest closed system model for bacterial growth. The same workability is experienced with Petri dishes, which also ensure bacterial growth by virtue of the presence of proteins and carbohydrates. An ideal culture of this sort would require the presence of salivary enzymes and a gradual supply of sucrose, simulating the oral environment ${ }^{15-19,23-25}$. This study used a culture medium and the bacterial species inoculated after a growth time of 24 hours were assessed as to their morphological and staining characteristics. With regard to the microorganism contamination scale, it was possible to observe, among the samples assessed, that all of them $(100 \%)$ were contaminated by GNC (gram-negative cocci), presenting a moderate contamination degree of $2.35 \pm 0.94+$, as well as by GPC (gram-positive cocci), with a contamination degree of $2.05 \pm 0.96+$. This is similar to the environment found in dental plaques with cariogenic potential, attributed mainly to $S$. mutans, corroborating the work of Esteves et al. ${ }^{25}$.

Ideally, CHX added to adhesive systems should be released in enough amounts to preserve binding to dentin over time without changing the mechanical properties of the polymer formed while preventing dental caries recurrence. This study revealed that the addition of CHX can inhibit bacterial growth. However, in view of the different composition of adhesives available on the market, this addition must be assessed according to the chemical formulation of the adhesive system being used in order to obtain the desired effect of CHX release in the dentin and oral environment.

\section{CONCLUSION}

It was possible to conclude that:

- The self-etching adhesive systems tested do not present antibacterial action;

- The addition of CHX promoted the antibacterial action;

- Increased CHX concentration did not result in increased antibacterial activity.

\section{REFERENCES}

1. Masarwa N, Mohamed A, Abou-Rabii I, Abu Zaghlan R, Steier L. Longevity of self-etch dentin bonding adhesives compared to etch-and-rinse dentin bonding adhesives: a systematic review. J Evid Based Dent Pract. 2016 Jun;16(2):96-106. http://dx.doi.org/10.1016/j.jebdp.2016.03.003. PMid:27449836.

2. Giannini M, Makishi P, Ayres AP, Vermelho PM, Fronza BM, Nikaido T, et al. Self-etch adhesive systems: a literature review. Braz Dent J. 2015 Jan-Feb;26(1):3-10. http://dx.doi.org/10.1590/01036440201302442 . PMid:25672377.

3. Van Meerbeek B, De Munck J, Yoshida Y, Inoue S, Vargas M, Vijay P, et al. Buonocore memorial lecture. Adhesion to enamel and dentin: current status and future challenges. Oper Dent. 2003 MayJun;28(3):215-35. PMid:12760693. 
4. Van Meerbeek B, Yoshihara K, Yoshida Y, Mine A, De Munck J, Van Landuyt KL. State of the art of selfetch adhesives. Dent Mater. 2011 Jan;27(1):17-28. http://dx.doi.org/10.1016/j.dental.2010.10.023. PMid:21109301.

5. Araújo MS, Souza LC, Apolonio FM, Barros LO, Reis A, Loguercio AD, et al. Two-year clinical evaluation of chlorhexidine incorporation in two-step self-etch adhesive. J Dent. 2015 Jan;43(1):140-8. http://dx.doi.org/10.1016/j.jdent.2014.07.010. PMid:25046536.

6. Nishitani Y, Hosaka K, Hoshika T, Yoshiyama M, Pashley DH. Effects of chlorhexidine in self-etching adhesive: 24 hours results. Dent Mater J. 2013;32(3):420-4. http://dx.doi.org/10.4012/dmj.2012-199. PMid:23719003.

7. Imazato S. Antibacterial properties of resin composites and dentin bonding systems. Dent Mater. 2003 Sep;19(6):449-57. http://dx.doi.org/10.1016/S0109-5641(02)00102-1. PMid:12837391.

8. Imazato S, Ma S, Chen JH, Xu HH. Therapeutic polymers for dental adhesives: loading resins with bioactive components. Dent Mater. 2014 Jan;30(1):97-104. http://dx.doi.org/10.1016/j.dental.2013.06.003. PMid:23899387.

9. Hugo WB, Longworth AR. Some aspects of the mode of action of chlorhexidine. J Pharm Pharmacol. 1964 Oct;16(10):655-62. http://dx.doi.org/10.1111/j.2042-7158.1964.tb07384.x. PMid:14226440.

10. Inagaki LT, Dainezi VB, Alonso RC, Paula AB, Garcia-Godoy F, Puppin-Rontani RM, et al. Evaluation of sorption/solubility, softening, flexural strength and elastic modulus of experimental resin blends with chlorhexidine. J Dent. 2016 Jun;49:40-5. http://dx.doi.org/10.1016/j.jdent.2016.04.006. PMid:27101768.

11. Pupo YM, Farago PV, Nadal JM, Simão LC, Esmerino LA, Gomes OM, et al. Effect of a novel quaternary ammonium methacrylate polymer (QAMP) on adhesion and antibacterial properties of dental adhesives. Int J Mol Sci. 2014 May;15(5):8998-9015. http://dx.doi.org/10.3390/ijms15058998. PMid:24853131.

12. Jacobo C, Torrella F, Bravo-González LA, Ortiz AJ, Vicente A. In vitro study of the antibacterial properties and microbial colonization susceptibility of four self-etching adhesives used in orthodontics. Eur J Orthod. 2014 Apr;36(2):200-6. http://dx.doi.org/10.1093/ejo/cjt032. PMid:23720449.

13. Licio CB, Teixeira JC, Rocha MMNP, Jacques PB. Atividade antimicrobiana de sistemas adesivos contra Streptococcus mutans, Candida spp e Staphylococcus aureus. FOL. 2016 Jul-Dez;26(2):53-60.

14. Carrilho MR, Tay FR, Donnelly AM, Agee KA, Tjäderhane L, Mazzoni A, et al. Host-derived loss of dentin matrix stiffness associated with solubilization of collagen. J Biomed Mater Res B Appl Biomater. 2009 Jul;90B(1):373-80. http://dx.doi.org/10.1002/jbm.b.31295. PMid:19090493.

15. Greenstein G, Polson A. The role of local drug delivery in the management of periodontal diseases: a comprehensive review. J Periodontol. 1998 May;69(5):507-20. http://dx.doi.org/10.1902/jop.1998.69.5.507. PMid:9623893.

16. Ebrahimi Chaharom ME, Ajami AA, Abed Kahnamouei M, Jafari Navimipour E, Tehranchi P, Zand V, et al. Antibacterial effect of all-in-one self-etch adhesives on Enterococcus faecalis. J Dent Res Dent Clin Dent Prospects. 2014;8(4):225-9. http://dx.doi.org/10.5681/joddd.2014.040. PMid:25587384.

17. Penmetsa RK, Rekha A S, Poppuri KC, Prashanth P S, Garapati S. An in vitro evaluation of antibacterial properties of self etching dental adhesive systems. J Clin Diagn Res. 2014 Jul;8(7):ZC01-05. http://dx.doi.org/10.7860/JCDR/2014/9010.4467. PMid:25177626.

18. Li Y, Carrera C, Chen R, Li J, Lenton P, Rudney JD, et al. Degradation in the dentin-composite interface subjected to multi-species biofilm challenges. Acta Biomater. 2014 Jan;10(1):375-83. http://dx.doi.org/10.1016/j.actbio.2013.08.034. PMid:24008178. 
19. Li F, Weir MD, Fouad AF, Xu HH. Effect of salivary pellicle on antibacterial activity of novel antibacterial dental adhesives using a dental plaque microcosm biofilm model. Dent Mater. 2014 Feb;30(2):182-91. http://dx.doi.org/10.1016/j.dental.2013.11.004. PMid:24332270.

20. Zhang K, Wang S, Zhou X, Xu HH, Weir MD, Ge Y, et al. Effect of antibacterial dental adhesive on multispecies biofilms formation. J Dent Res. 2015 Apr;94(4):622-9. http://dx.doi.org/10.1177/0022034515571416. PMid:25715378.

21. Imazato S, Kinomoto Y, Tarumi H, Ebisu S, Tay FR. Antibacterial activity and bonding characteristics of an adhesive resin containing antibacterial monomer MDPB. Dent Mater. 2003 Jun;19(4):313-9. http://dx.doi.org/10.1016/S0109-5641(02)00060-X. PMid:12686296.

22. Cocco AR, Rosa WL, Silva AF, Lund RG, Piva E. A systematic review about antibacterial monomers used in dental adhesive systems: current status and further prospects. Dent Mater. 2015 Nov;31(11):134562. http://dx.doi.org/10.1016/j.dental.2015.08.155. PMid:26345999.

23. Breschi L, Cammelli F, Visintini E, Mazzoni A, Vita F, Carrilho M, et al. Influence of chlorhexidine concentration on the durability of etch-and-rinse dentin bonds: a 12-month in vitro study. J Adhes Dent. 2009 Jun;11(3):191-8. PMid:19603582.

24. Shafiei F, Alikhani A, Alavi AA. Effect of chlorhexidine on bonding durability of two self-etching adhesives with and without antibacterial agent to dentin. Dent Res J (Isfahan). 2013 Nov;10(6):795801. PMid:24379870.

25. Esteves CM, Ota-Tsuzuki C, Reis AF, Rodrigues JA. Antibacterial activity of various self-etching adhesive systems against oral streptococci. Oper Dent. 2010 Jul-Aug;35(4):448-53.

http://dx.doi.org/10.2341/09-297-L. PMid:20672730.

\section{CONFLICTS OF INTERESTS}

The authors declare no conflicts of interest.

\section{*CORRESPONDING AUTHOR}

Veridiana Camilotti, UNIOESTE - Universidade Estadual do Oeste do Paraná, Faculdade de Odontologia, Rua Universitária, 1619, 85819-110 Cascavel - PR, Brasil, e-mail: vericamilotti@hotmail.com

Received: October 182017

Accepted: February 7, 2019 